\title{
IMPROVING THE APPROACH TO THE IMPLEMENTATION OF FOREIGN LANGUAGE COMMUNICATIVE ACTIVITIES OF STUDENTS IN THE CONTEXT OF THE UPDATED CONTENT OF EDUCATION
}

\author{
Aiganym Galym ${ }^{1}$, Valentina Maximova ${ }^{2}$ \\ ${ }^{1}$ E.A.Buketov Karaganda University, Karaganda, Kazakhstan \\ ${ }^{2}$ E.A.Buketov Karaganda University, Karaganda, Kazakhstan \\ ORCID ID: 0000-0001-8234-5122
}

\begin{abstract}
This article is devoted to communicative activity of students, which is a necessary component in learning any foreign language. The authors reveal the importance of improving the approach to the implementation of tasks in the lessons with communicative orientation, as well as the use of modern approaches in foreign language teaching in accordance with the leading challenges and strategies of the updated content of education of the Republic of Kazakhstan.

The author analyzes modern methods and techniques aimed not only at improving the communicative skills of students, but also in parallel contributes to the development of critical thinking skills and the formation of functional literacy students.
\end{abstract}

\section{INTRODUCTION}

The system of social relations and its changes in the modern world have a significant impact on the educational system of each country, so as education that is given the leading role in preparing the future generation that meets the requirements of global competitiveness in education and the needs of economic development of the country. In accordance with this challenge, the course for updating the content of the education system in the Republic of Kazakhstan has been determined and its implementation has already passed through several stages, and has shown its effectiveness.

The leading concept of the renewed educational structure is the overcoming of the traditional reproductive style of teaching and the transition to a new developmental and constructive model of education. This model aims to improve the methods and methodological support of the educational process, as well as to develop a new teacher's view of his/her role and place and, of course, attitude towards the pupil [State Programme of Education Development of the Republic of Kazakhstan, 2010].

In our point of view, the approach to teaching foreign languages, particularly English, has changed, where foreign-language communication is now given a primary role in the classroom. Nowadays, many modern methods insist on communicative learning, e.g. language immersion method, dialogic learning. We see the main reason as the fact that communication is nowadays the main need to improve one's language skills, because now speaking a foreign language is not a goal, but a tool leading to further perspectives.

English language teaching in secondary and higher education is also changing its attitudes, among which the designation of requirements for practical mastery of the target language in the four types of speech activities in the form of expected learning objectives is fundamentally new in the renewed educational programme. These goals become more complex both from one grade to the next, and as the speech activity skill develops.

Considering a modern lesson, its form of carrying out and approaches of teaching, it is impossible not to touch activity of the teacher who directs and organizes active cognitive activity of students, and also creates all kinds of conditions and atmosphere at lessons promoting opening of potentialities of students and development of their creative abilities. This is possible only if the teacher's position is changed, which is expressed in the organization of their interaction: cooperation, joint creativity, management of cognitive activity, democratic style of communication. 
Thus, nowadays, the main task of a modern teacher is not just to give new material and reinforce it with test tasks, but to motivate students to search activities aimed at the development of critical thinking skills and analysis of necessary information for further practical application in life by organizing a collaborative environment in the classroom. This reinforcement of person-centered education is possible through the application of various modern interactive teaching methods and innovative pedagogical technologies aimed at improving students' functional literacy and communicative activities [National Academy of Education named after I. Altynsarin, 2018].

Considering the content, one of the most debated aspects of the problem of foreign language teaching is still the testing and recording of knowledge, skills and abilities, the methodology of their organization and implementation, leading to the development of the communicative skills of the foreign language learner.

Undoubtedly, the learning situation should stimulate the motivation to learn, arouse the pupil's interest in the task and a desire to do it well. It is important to give the speech as early as possible a communicative character, a nature of natural communication, to give students the opportunity to express their own thoughts and to enjoy speaking a foreign language. Communicative ability is a complex psychological formation developing on the basis of communicative prerequisites, including such structural components as emotional, cognitive, self-assessment, communicative-activation, which are in close connection with each other and ensure the success of communicative activity.

Communicative abilities as a dynamic formation are distinguished by such psychological features as individual degree of expression; integrity of functioning of structural components; ensuring the success of communicative activity; irreducibility of communicative abilities to communicative knowledge, skills and abilities [Khuzhanijazova, 2013].

As we know, the basic idea of renewed educational content includes the widespread introduction of innovative, active forms of learning in which pupils develop their functional literacy independently, actively 'gain' the necessary knowledge, develop communication skills with their peers and surrounding adults, and think creatively about how to solve different problems [State programme for the development of education and science of the Republic of Kazakhstan, 2016].

Since the main focus of communicative activities in the classroom is to create the illusion of being in the natural language environment in order to make contact with another person and discuss a topic. Hence, the approach to the implementation of this kind of activity tasks in the classroom must necessarily improve, taking into account modern methods, technologies and fresh ideas of the new generation.

Certainly, each student has certain individual communication needs and each has a different interest in certain activities. A variety of verbal, visual and practical teaching methods make lessons completely different from standard lessons, giving students the opportunity to speak fluently, to learn independently, and oriented to listen to each other.

It is worth highlighting the application of the following forms and modern teaching technologies on the lessons, which lead not only to the implementation of the above-mentioned points, but also to the active strengthening of students' communicative skills. Such as, problemdialogue teaching, language immersion method, search method, games with communicative orientation. Their importance and peculiarity is to teach students to think and find solutions in a foreign language, sometimes even to non-standard situations, using active speech interaction. The difference between these approaches and technologies lies in the implementation and form of the lessons. So, for example, the problem-dialogue teaching implies the teacher's organization of the search for a solution through prompting or leading dialogue, or "discovery" of new knowledge; in the method of language immersion at best new principles of selection and organization of speech and language material are applied, of which the leading ones are activity-based, person-role, situationthematic principles [Elagina, Nemudraya, 2009].

Also, one of the important factors for the effectiveness of the above-mentioned modern teaching methods and techniques applied in the English language lesson is a set of certain formative and preparatory pedagogical conditions. Such as the use of authentic materials for a natural communicative setting, discussions for solving tasks that mobilize knowledge and experience, 
conducting self-reflection to develop a sense of responsibility, as well as supporting each student in active communicative participation in the lesson help and stimulate students regardless of their language proficiency level.

It is worth highlighting that it is secondary education in the renewed curriculum that should begin to build students' self-education skills, making them more independent, self-motivated, more enthusiastic, confident, responsible individuals with a more developed critical thinking, who will show competence in digital technologies.

Also, we want to highlight, knowledge given in a foreign language should be learned qualitatively, not memorized. Thus, communication in a foreign language can be taught only by speaking in that language.

A communicative situation can be based on a single topic (for example, shopping in a store) or it can cover several topics (for example, organizing a discussion of a movie that you have watched).

Speaking about the new structure of the updated curricula, it is impossible not to touch upon the importance of application and competence in the use of information and communication technologies in English lessons. For the successful implementation of the updated content of education, subject teachers should have ICT competencies, use additional resources, including the Internet and form students' skills in finding, processing information on the subject. ICT resources in education include a variety of hardware and software tools for particular pedagogical tasks, with subject matter content and learner-centered interaction.

The advantages of introducing Internet technologies into the process of teaching English are currently beyond doubt. The use of Internet technologies provides a unique opportunity to connect with any part of the world by means of search engines. Learning is already going beyond the classroom to the limitless.

Of the current types of educational software, we would like to highlight the use of the subject sampler, which is one of the steps towards the use of information technology. It also contains links to text and multimedia material on the Internet. After studying each aspect of the topic, the students need to answer the questions posed, but the questions are not aimed at factual learning of the material, but at discussing discussion topics. The students do not only need to familiarize themselves with the material, but also to express and argue their opinion on the issue under discussion.

We would like to point out that most pupils already have a strong interest and enthusiasm for foreign language communication in their free time. This includes listening to texts on topics of interests in extracurricular time, attending speaking clubs at organized educational centers, selforganize of team-building activities, speaking clubs, watching videos for listening narratives by native speakers and discussing them with classmates.

As noted earlier, the modernization of the secondary education system of our country has not only contributed to qualitative changes, but also entailed innovations in the system of assessment of knowledge and skills of students acquired during the period of learning activities. That is, introduction of criteria form of an estimation among which formative estimation represents the process of the check, defining current level of development of knowledge and formation of skills of students at a lesson, at home, realizing the operative communication between the student and the teacher during training, allowing students to understand how correctly they perform tasks during learning of new material and achievement of objectives of training [Alike, Bugenova, 2017].

We would like to point out the effectiveness and importance of this kind of approach to checking the readiness and achievement of students. Because if in the traditional format the student was guided by a grade and worked towards it, now the student is guided by the teacher's prompts and advice, which in this way can further motivate the student to improve their pronunciation and activity. The student, with the help of teacher directions and work in pairs or groups, formulates his or her opinion and emphasizes self-reflection. Mutual evaluation in English lessons also helps students to open up both on the part of an objective viewer as well as on the part of improving students' communicative competences.

Due to oral communication includes speaking and listening, it cannot be overlooked that of the four types of speech activity, listening accounts for the least amount of time allocated in a foreign 
language lesson, although from the perspective of improving students' oral speech activity, listening plays no less important a role than speaking. Hence the lack of development of proper English language proficiency, even among final-year pupils, characterized by difficulties in perceiving and analysing information perceived aurally. Continuous implementation of listening comprehension in English lessons allows students to immerse themselves in the language environment and helps to create favorable conditions for their gradual overcoming of the language barrier. Therefore, today, in the process of teaching English in accordance with the objectives of the renewed education system, teachers simply need to improve the teaching methodology and approach to each lesson by applying innovative technologies in the implementation of listening in conjunction with active speaking in English lessons [Muhammad, 2015].

Consider the features of the approach to the implementation of speaking and listening in the classroom, taking into account the concept of renewed secondary education. Since the process of natural communicative activity is characterized by a single presentation, low throughput of the auditory canal and the inability to change the rate of the speaker's speech in accordance with the speed of its processing by the recipient, in the organization of the lesson it is necessary to more often use tasks for performing various mental operations - analysis, synthesis, generalization, which help students quickly perceive and analyze information, extract the key idea from it, as well as predict the meaning of the speaker and formulate their answer or the opposite thought.

To enhance the student's interest in the classroom, it is important to first awaken in him research, creative activity, and then create the necessary conditions for him to comprehend the material and then help him to generalize the acquired knowledge. I would like to highlight the case study method, which is based on the ability to listen, take into account an alternative point of view and express your own, orient yourself and adapt to a new linguistic environment, and remain face to face with real situations when solving a problem problem of a case. With the help of this method, students have the opportunity to be ready to work in a team, to find the most rational solution to the task at hand. Analytical and communication skills are formed and developed, research activities are carried out. It is natural to use situational analysis both for teaching professional and everyday communication.

The structure of the case study method is designed to organize tasks based on a concrete situation of direct relevance to the practical side of everyday life. The students then have to identify a contradiction, discuss it in English, identify alternative ways of solving it and then propose their own solutions to the problem, which are properly justified and then presented to all the students. It is worth noting that there is no single correct solution in solving the cases, as they are directly related to pressing problems and contradictions from life, so at the end of the contradiction resolution presentations by all groups of students, the teacher or students themselves can choose the most appropriate solution [Jadmenova, Tsay, 2021].

Of course, this method is more suitable for an older school phase or for language students, where students can actively express their opinions and knowledge without the use of dictionaries.

\section{CONCLUSIONS}

In order to develop oral speech activity, it is advisable to carry out pedagogical activities in accordance with the communicative-activity approach and the use of interactive technologies. Such an approach is implemented through the use of active and interactive methods, participation in project activities, mastery of research methods, involvement of students in play, assessment and discussion, reflective activities, as well as project activities, which provide a free search for an effective approach to solving the problem that meets the child's individuality. Here, audiovisual and communicative in combination are very effective methods. Among them, the audiovisual method is not limited to the framework of structures, but pays great attention to their use in communication situations, the communicative method helps in all ways to achieve language learning within real situations, which allows you to quickly and naturally master communication skills and easily apply English in everyday life. 
Thus, it is possible to single out a significant variety of methods and techniques aimed at improving the communicative activity of students at different stages of learning, the effectiveness of which directly depends on the goal and approach of each teacher.

But, undoubtedly, maintaining the constant interest of students is considered to be a very significant factor in improving the approach of each teacher to the implementation of tasks for the active speech interaction of students with each other in the classroom. That is, their constant motivation, in which the basis is: the correct selection of tasks, in accordance with the level of students' language proficiency, the formation of an adaptive communication situation, and a variety of tasks that involve the control and timely direction of each student, the use of a symbiosis of methods and approaches aimed at disclosing communicative activity of each student.

\section{REFERENCES:}

Alike E., Bugenova L.A. (2017). Razvitie trechjazychija v Kazakhstane (analiz poslanija prezidenta Respubliki Kazakhstan) [Development of trilingualism in Kazakhstan (analysis of the messages of the President of the Republic of Kazakhstan)] // Materialy XII Mezhdynarodnoj nauchnoprakticheskoj konferencii KazATK imeni M. Tynyshpayeva - Materials of the XII International Scientific-Practical Conference of KazATC named after M. Tynyshpayev. T. 3. pp.336-340 [in Russian].

Elagina V. S., Nemudraya E. (2009). Kommunikativnaya dejatelnost kak vazhnaya sostavljaushchaja pedagogicheskoj kompetentnosti uchitelja [Communication activity as an important part of the pedagogical competence of a teacher] // Mezhdunarodnyi zhurnal yeksperimentalnogo obrazovanija - International Journal of Experimental Education, No. 5, p.41 [in Russian], https://expeducation.ru/ru/article/view?id=138

Gosudarstvennaja programma razvitija obrazovanija i nauki Respubliki Kazakhstan na 2016-2019 gody ot 1 marta 2016 goda №205 - State programme for the development of education and science of the Republic of Kazakhstan for 2016-2019, Astana, Kazahstan [in Russian], http://psu.kz/images/october2014/gpro.pdf

Instruktivno-metodicheskoe pis'mo «Ob osobennostjah organizacii obrazovatel'nogo processa $\mathrm{V}$ obshcheobrazovatelnyh shkolah Respubliki Kazakhstan» - About the peculiarities of the organization of the educational process in general education schools in the Republic of Kazakhstan. Natsionalnaja academia obrazovanija im.I. Altynsarina - [National Academy of Education named after I. Altynsarin], 2018.: Astana, Kazakhstan.

Jadmenova D.A., Tsay E. (2021) Case study method for English language teaching. // Materials of the scientific journal "International scientific review", p. 40-43.

Khuzhanijazova G. (2013). Govorenie kak tsel obuchenija anglijskomu jazyku [Speaking as the aim of teaching English]. Aktual'nyye voprosy sovremennoj pedagogiki: materialy III mezhdunarodnoy nauchnoy konferencii - Actual issues of modern pedagogy: proceedings of the III International Scientific Conference, march 2013.: Ufa, Russia - pp.15-18 [in Russian].

Muhammad U. (2015). Creating a communicative language teaching environment for improving students' communicative competence at EFL/EAP university level: A literature review // Canadian Center of Science and Education - International Education Studies, Vol. 8, No. 4, 30 march 2015, pp. 179-191, http://dx.doi.org/10.5539/ies.v8n4p179

Ukaz Prezidenta Respubliki Kazakhstan «Ob utverzdenii Gosudarstvennoj programmy razvitija obrazovanija Pespubliki Kazakhstan na 2011-2020 gody» ot 7 dekabrja 2010 goda № 1118 Presidential Decree on approval of the State Programme of Education Development of the Republic of Kazakhstan for 2011-2020, Astana, Kazakhstan [in Russian]. 